\title{
Kajian Variasi Ketebalan Tumpukan Fermentasi Terhadap Kualitas Pliek U dan Minyak Pliek Yang Dikeringkan Dengan Alat Pengering Tipe Hohenheim
}

\author{
(Study on Thickness Variation Fermented of Quality Pliek U and Oil Pliek \\ to Drained By Equipment Type Dryer Hohenheim )
}

\author{
Muhammad Al-Hasani $^{1}$, Zulfahrizal ${ }^{1}$, Raida Agustina $^{{ }^{*}}$ \\ ${ }^{1}$ Program Studi Teknik Pertanian, Fakultas Pertanian, Universitas Syiah Kuala
}

\begin{abstract}
Abstrak. Masyarakat Aceh secara turun-temurun telah menggunakan daging buah dan minyak kelapa terfermentasi (diperam) yang diproses secara tradisional. Minyak kelapa yang dihasilkan salah satunya dikenal dengan nama minyak pliek yang digunakan sebagai minyak goreng dan juga dimanfaatkan sebagai obat untuk sakit kepala, luka, menurunkan panas, sakit persendian, dan sakit perut. Ampas yang diperoleh setelah pengepresan disebut pliek $u$, yang digunakan sebagai bumbu masakan. Tujuan dari penelitian ini adalah mengkaji kualitas dari pliek $u$ dan minyak pliek dengan variasi ketebalan tumpukan fermentasi $30 \mathrm{~cm}, 20 \mathrm{~cm}$, dan $10 \mathrm{~cm}$. Hasil penelitian menunjukkan bahwa pliek $u$ dan minyak pliek yang paling diterima oleh panelis adalah ketebalan tumpukan fermentasi $30 \mathrm{~cm}$. Berdasarkan hasil penelitian jumlah rendemen tertinggi pliek $u$ dan minyak pliek terdapat pada ketebalan $30 \mathrm{~cm}$. Kadar air setelah fermentasi dan kadar air pliek $u$ yang dihasilkan pada setiap variasi ketebalan $30 \mathrm{~cm}, 20 \mathrm{~cm}$ dan $10 \mathrm{~cm}$ relatif sama, yakni berkisaran antara 57,6\% $60,0 \%$ untuk kadar air setelah fermentasi dan 4,4\% - 6,5\% untuk kadar air pliek u. Hasil pH pliek u lebih besar dibandingkan $\mathrm{pH}$ setelah fermentasi, namun nilai yang dihasilkan tidak melebihi angka 7 (netral), hal ini berlaku untuk setiap variasi ketebalan bahan. Secara keseluruhan minyak pliek yang dihasilkan masih memenuhi standar SNI. Minyak pliek yang dihasilkan dari ketebalan $30 \mathrm{~cm}$ yang memiliki kualitas terbaik karena memiliki kadar asam lemak bebas terkecil yaitu sebesar $0,39 \%$. Hasil pengujian organoleptik terhadap pliek $u$ dan minyak pliek dapat disimpulkan bahwa masyarakat lebih menerima pliek $u$ dan minyak pliek dengan ketebalan fermetasi $30 \mathrm{~cm}$.
\end{abstract}

Kata kunci : Kelapa, pengeringan, pliek u, minyak pliek, kualitas.

\begin{abstract}
The people of Aceh for generations have used fruit pulp and palm oil fermented (ripened) are processed traditionally. Coconut oil is produced by one of them known as pliek oil that is used as a cooking oil and is also used as a remedy for headaches, cuts, lower the heat, joint pain, and abdominal pain. The pulp obtained after pressing is name (oil pliek), which is used as a spice in cooking. The purpose of this study is to assess the quality of pliek $u$ and oil pliek with thickness variation heap of fermentation $30 \mathrm{~cm}, 20 \mathrm{~cm}$ and $10 \mathrm{~cm}$. The results showed that pliek $u$ and oil pliek the most accepted by the panelists is $30 \mathrm{~cm}$ thick pile fermentation. Based on the results of the study the number of the highest yield and oil pliek pliek $u$ are at a thickness of $30 \mathrm{~cm}$. The water content after fermentation and water content pliek $\mathrm{u}$ generated on every variation of the thickness of $30 \mathrm{~cm}$, $20 \mathrm{~cm}$ and $10 \mathrm{~cm}$ are relatively the same, ie ranging between $57.6 \%-60.0 \%$ for water content after fermentation and $4.4 \%-6,5 \%$ for water content pliek u. Results pliek u pH greater than $\mathrm{pH}$ after fermentation, but the resulting value does not exceed the number 7 (netral), this proses every variation of the thickness of the material. Overall oil produced pliek still meet ISO standards. Pliek oil produced from a thickness of $30 \mathrm{~cm}$ that has the best quality because it has the smallest free fatty acid content is $0.39 \%$. The test results organoleptic pliek poil can be concluded that the public is receiving pliek $\mathrm{u}$ and oil fermetasi pliek with a thickness of $30 \mathrm{~cm}$.
\end{abstract}

Keywords: Coconut, drying, pliek u, oil pliek, quality

\section{PENDAHULUAN}

Luas tanaman kelapa mulai turun sejak tahun 2005, terutama akibat tsunami yang menyebabkan banyak tanaman rusak. Upaya rehabilitasi tanaman tidak mampu meningkatkan produksi dan produktivitas tanaman kelapa rakyat ini. Oleh 
sebab itu produksi kelapa di daerah ini mulai tahun 2005 menurun rata-rata 9 persen pertahun dengan perkiraan 33.833 ton (Romano, 2013).

Kelapa (Cocos nucifera L.) telah digunakan baik sebagai makanan maupun obat selama berabad-abad di berbagai kebudayaan di seluruh dunia, termasuk Indonesia. Masyarakat Provinsi Aceh secara turun-temurun telah menggunakan daging buah dan minyak kelapa terfermentasi (diperam) yang diproses secara tradisional. Minyak kelapa yang dihasilkan dikenal dengan nama minyak simplah dan minyak pliek $u$ yang digunakan sebagai minyak goreng dan juga dimanfaatkan sebagai obat untuk sakit kepala, luka, menurunkan panas, sakit persendian, dan sakit perut. Ampas yang diperoleh setelah diambil minyaknya disebut pliek $u$ (patarana), yang digunakan sebagai bumbu masak (Nurliana dkk, 2009).

Menurut Suhardiyono (1988), tanaman kelapa disebut juga "pohon kehidupan" karena dari setiap bagian tanaman dapat dimanfaatkan untuk memenuhi kebutuhan hidup manusia. Buah kelapa yang terdiri atas serabut, tempurung, daging buah, dan air kelapa tidak ada yang terbuang dan dapat dibuat untuk menghasilkan produk industri, antara lain sabut kelapa dapat dibuat keset, sapu, dan matras.

Selanjutnya Suhardiyono (1988) menambahkan daging buah dapat dipakai sebagai bahan baku untuk menghasilkan kopra, minyak kelapa, santan, dan kelapa parut kering (desiccated coconut), sedangkan air kelapa dapat dipakai untuk membuat cuka dan nata de coco. Tempurung dapat dimanfaatkan untuk membuat karbon aktif dan kerajinan tangan, dari batang kelapa dapat dihasilkan bahan-bahan bangunan baik untuk kerangka bangunan maupun dinding serta atap. Daun kelapa dapat diambil lidinya yang dapat dipakai sebagai sapu, serta barang-barang anyaman.

\section{Waktu dan Tempat}

\section{METODE PENELITIAN}

Penelitian ini dilaksanakan pada tanggal 28 Januari 2016, 09 April 2016 dan 03 Mei 2016 di kebun percobaan Fakultas Pertanian dan Laboratorium Teknik Pasca Panen, Program Studi Teknik Pertanian, Universitas Syiah Kuala Darussalam Banda Aceh.

\section{Alat dan Bahan}

Alat yang digunakan pada penelitian ini adalah wadah fermentasi (ember), satu unit alat pengering surya tipe Hohenheim, alat pres tipe dongkrak hidrolik, Benchtop pH meter 86505,Humdity meter, dan timbangan digital. Bahan yang digunakan dalam penelitian ini adalah kelapa kukur yang telah difermentasi dengan variasi perlakuan terhadap ketebalan $(30 \mathrm{~cm}, 20 \mathrm{~cm}$, dan $10 \mathrm{~cm})$ selama 7 hari fermentasi.

\section{Metode Penelitian}

Tahapan penelitian ini dimulai dari buah kelapa yang umur panennya sudah sangat tua dibelah kemudian dikukur. Selanjutnya kelapa kukur ditimbang. Kemudian dimasukkan ke dalam 3 wadah yang sama dengan variasi ketebalan $10 \mathrm{~cm}, 20 \mathrm{~cm}$, dan $30 \mathrm{~cm}$. Fermentasi dilakukan selama 7 hari dan dilakukan pengadukan dua kali sehari. Selama fermentasi tiap-tiap perlakuan akan mengeluarkan minyak simplah. Setelah hari ke 7 selanjutnya bahan dikeringkan dengan menggunakan alat pengering tipe hohenheim selama 2 hari. Selanjutnya dilakukan pengrepesan dengan menggunakan alat pres tipe hidrolik, saat 
pengepresan bahan akan mengahsilkan minyak pliek dan bahan yang tidak mengeluarkan minyak lagi disebut pliek $\mathrm{u}$.

\section{Parameter Penelitian}

Selama pengeringan berlangsung, diukur temperatur lingkungan dan temperatur alat, kelembaban, iradiasi surya, rendemen, kadar air, $\mathrm{pH}$, asam lemak bebas, dan organoleptik.

\section{Fermentasi Kelapa Kukur}

\section{HASIL DAN PEMBAHASAN}

Proses mendapatkan pliek- $u$ dan minyak pliek yang harus dilakukan yaitu fermentasi kelapa kukur. Proses ini berlangsung selama 7 hari dengan variasi ketebalan tumpukan fermentasi yaitu $30 \mathrm{~cm}, 20 \mathrm{~cm}$ dan $10 \mathrm{~cm}$. Wadah yang digunakan ember berwarna hitam sebanyak 3 buah, yang masing-masing ember diisi dengan kelapa kukur dengan ketebalan $30 \mathrm{~cm}, 20 \mathrm{~cm}$ dan $10 \mathrm{~cm}$. Penutup yang digunakan pada saat proses fermentasi menggunakan daun pisang (Gambar 1.)

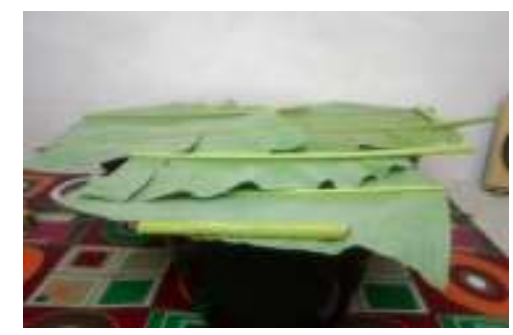

Gambar 1. Kelapa kukur fermentasi di tutup dengan daun pisang

Pengadukan selama proses fermentasi dilakukan 2 kali dalam 1 hari, dengan jadwal pengadukan pagi dan sore hari yang dilakukan terus menerus sampai hari ke 7. Pada tahap fermentasi kelapa kukur akan menghasilkan minyak simplah yang berguna sebagai obat sakit kepala, menurunkan panas, sakit persendian dan sakit perut.

Hasil fermentasi kelapa kukur ketebalan $30 \mathrm{~cm}$ menghasilkan warna yang tidak terlalu kehitaman, tekstur tidak terlalu lengket dan tidak berbau. Hal ini dapat dilihat pada Gambar 2.
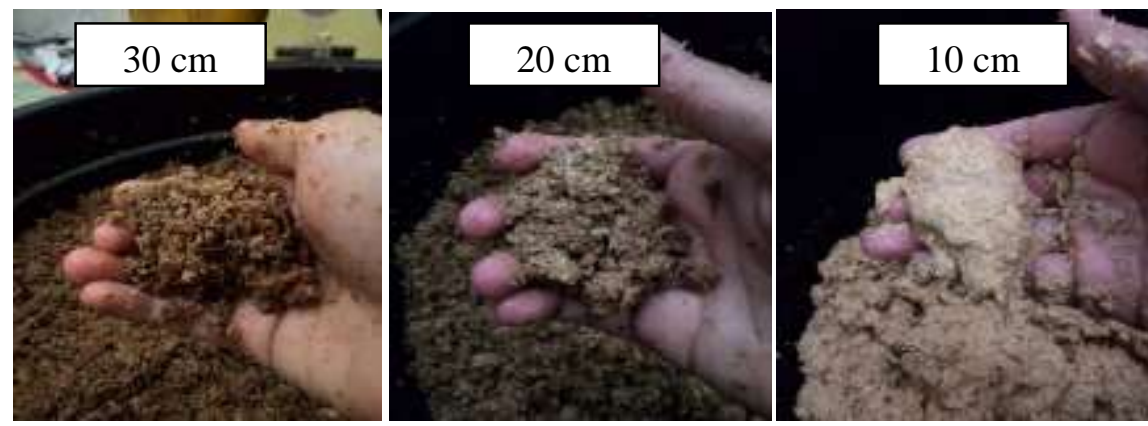

Gambar 2. Hasil kelapa kukur fermentasi ketebalan $30 \mathrm{~cm}, 20 \mathrm{~cm}, 10 \mathrm{~cm}$.

Ketebalan $20 \mathrm{~cm}$ memiliki tekstur yang sedikit lengket dan berwarna keputihan masih terlihat seperti awal kelapa kukur. Hasil ketebalan $10 \mathrm{~cm}$ 
teksturnya sangat lembek seperti bubur, berwarna putih, tekstur lembek seperti bubur dan beraroma tidak sedap. Hasil keduanya ketebalan tersebut dapat dilihat pada Gambar 2.

\section{Karakteristik Pengeringan}

Pengeringan pliek $u$ menggunakan alat pengering tipe Hohenheim. Pengeringan dilakukan selama 16 jam (2 hari) dapat disimpulkan bahwa data suhu dan RH selama pengeringan memliki nilai yang berbeda, jika suhu tinggi maka RH yang dihasilkan rendah dan sebaliknya jika suhu rendah, RH yang dihasilkan tinggi. Hal tersebut dapat dilihat pada Tabel 1.

Tabel 1. Karakteristik pengeringan pliek $u$ menggunakan alat tipe Hohenheim

\begin{tabular}{ccccccccc}
\hline \multirow{2}{*}{$\begin{array}{c}\text { Waktu } \\
(\text { WIB })\end{array}$} & \multicolumn{2}{c}{ Suhu $\left({ }^{\circ} \mathbf{C}\right)$} & \multicolumn{2}{c}{$\begin{array}{c}\text { Kelembaban Relatif } \\
(\mathbf{\%})\end{array}$} & \multicolumn{2}{c}{$\begin{array}{c}\text { Iradiasi Surya } \\
\left(\mathbf{W} / \mathbf{m}^{2}\right)\end{array}$} & \multicolumn{2}{c}{$\begin{array}{c}\text { Suhu } \\
\text { Lingkungan }\end{array}$} \\
\cline { 2 - 10 } & $\mathbf{H a r i}$ & Hari 2 & Hari 1 & Hari 2 & Hari 1 & Hari 2 & Hari 1 & Hari 2 \\
\hline 8 & 29 & 30 & 53,4 & 55,0 & 36,2 & 28,6 & 28 & 27 \\
9 & 30 & 31 & 52,7 & 54,3 & 87,6 & 91,4 & 29 & 28 \\
10 & 34 & 39 & 46,1 & 41,9 & 262,9 & 264,8 & 31 & 32 \\
11 & 52 & 48 & 44,6 & 35,6 & 681,9 & 636,2 & 34 & 34 \\
12 & 59 & 60 & 28,9 & 27,7 & 838,1 & 841,9 & 35 & 35 \\
13 & 54 & 58 & 32,1 & 29,5 & 807,6 & 577,1 & 34 & 33 \\
14 & 51 & 56 & 33,8 & 31,9 & 721,9 & 415,2 & 34 & 32 \\
15 & 50 & 54 & 36,6 & 33,6 & 413,3 & 299,0 & 32 & 31 \\
16 & 44 & PS & 40,7 & PS & 278,1 & PS & 31 & PS \\
17 & 37 & PS & 48,1 & PS & 68,6 & PS & 30 & PS \\
\hline Rata-rata & $\mathbf{4 4}$ & $\mathbf{4 7}$ & $\mathbf{4 2}$ & $\mathbf{3 9}$ & $\mathbf{4 2 0}$ & $\mathbf{3 9 4}$ & $\mathbf{3 2}$ & $\mathbf{3 1}$ \\
\hline Std Deviasi & $\mathbf{1 1}$ & $\mathbf{1 2}$ & $\mathbf{9}$ & $\mathbf{1 1}$ & $\mathbf{3 1 8}$ & $\mathbf{2 7 9}$ & $\mathbf{3}$ & $\mathbf{3}$ \\
\hline Maksimum & $\mathbf{5 9}$ & $\mathbf{6 0}$ & $\mathbf{5 3 , 4}$ & $\mathbf{5 3 , 7}$ & $\mathbf{8 3 8 , 1}$ & $\mathbf{8 4 1 , 9}$ & $\mathbf{3 5}$ & $\mathbf{3 5}$ \\
\hline Minimum & $\mathbf{2 9}$ & $\mathbf{3 0}$ & $\mathbf{2 8 , 9}$ & $\mathbf{2 6 , 8}$ & $\mathbf{3 6 , 2}$ & $\mathbf{2 8 , 6}$ & $\mathbf{2 8}$ & $\mathbf{2 7}$ \\
\hline
\end{tabular}

Pada pengeringan hari ke-1 bahan belum berwarna kecoklatan secara keseluruhan, sedangkan hari ke-2 menunjukkan bahan sudah berwarna kecoklatan secara keseluruhan, maka dari itu bahan sudah bisa dilakukan proses pengepresan dengan menggunakan alat pres tipe hidrolik. Data tersebut adalah data yang sudah dirata-ratakan pada setiap pengulangan dan setiap ketebalan, untuk data lengkap bisa dilihat pada lampiran 3 .

Suhu dan RH sangat berpangaruh terhadap pengeringan. Jika suhu pada saat pengeringan tinggi maka RH yang dihasilkan rendah. Hal ini sejalan dengan pernyataan Taib,dkk. (1987) yang menyatakan bahwa apabila terjadi kenaikan suhu sebanyak $1^{\circ} \mathrm{C}$ maka nilai kelembabanrelatif (RH) akan turun sebanyak $4 \%$.

Kelembaban udara berpengaruh terhadap proses pemindahan uap air. Menurut Taib dkk. (1988) tekanan uap tergantung pada kelembaban udara. Taufiq (2008) menambahkan bahwa apabila kelembaban udara tinggi, maka perbedaan tekanan uap air di dalam dan di luar bahan menjadi kecil sehingga menghambat 
pemindahan uap air dari dalam bahan ke luar dan menyebabkan pemindahan aliran cairan tersebut sedikit.

\section{Rendemen Pliek $\boldsymbol{U}$ dan Minyak Pliek}

Rendemen merupakan perbandingan antara output dan input hasil penelitian yang direpresentasikan dalam bentuk presentase. Pada penelitian ini outputnya ada 2 macam yaitu pliek $u$ dan minyak pliek sedangkan inputnya adalah kelapa kukur.

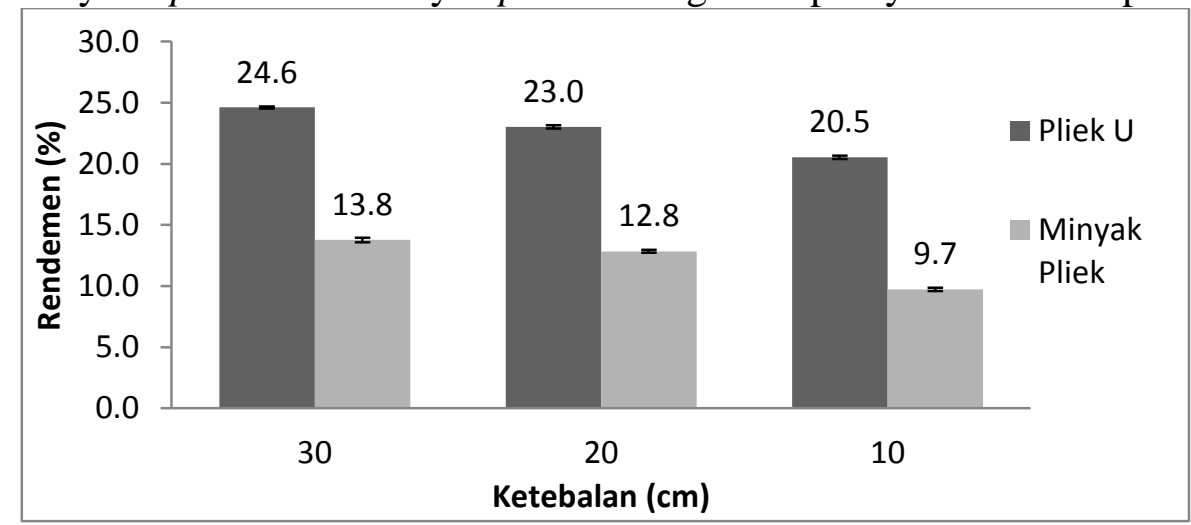

Gambar 3. Hasil rendemen pliek-u dan minyak pliek

Ketebalan $30 \mathrm{~cm}$ berat awal kelapa kukur sebesar $24 \mathrm{~kg}$, pliek- $u$ yang dihasilkan sebesar 5,9 kg, minyak pliek yang dihasilkan sebesar 2,5 kg. Dari data tersebut dapat disimpulkan rendemen pliek $u$ yang dihasilkan sebesar 24,6 $\pm 0,1 \%$, sedangkan rendemen minyak pliek yang dihasilkan sebesar 13,8 $\pm 0,2 \%$.

Ketebalan $20 \mathrm{~cm}$ berat awal kelapa kukur $14,8 \mathrm{~kg}$, pliek- $u$ yang dihasilkan sebesar 3,4 kg, minyak pliek yang dihasilkan sebesar 1,4 kg. Dari data tersebut dapat disimpulkan rendemen pliek $u$ yang dihasilkan sebesar $23 \% \pm 0,1$, sedangkan rendemen minyak pliek sebesar $12,8 \pm 0,1 \%$.

Ketebalan $10 \mathrm{~cm}$ berat awal kelapa kukur sebesar $6,5 \mathrm{~kg}$, pliek- $u$ yang dihasilkan sebesar $1,3 \mathrm{~kg}$, minyak pliek yang dihasilkan sebesar 0,4 kg. Dari data tersebut dapat disimpulkan rendemen pliek $u$ yang dihasilkan sebesar $20,5 \pm 0,1 \%$, sedangkan rendemen minyak pliek sebesar $9,7 \pm 0,1 \%$.

\section{Kualitas Produk}

\section{Kadar Air Pliek-U}

Kadar air kelapa setelah fermentasi ketebalan $30 \mathrm{~cm}$ sebesar 57,6 0 ,3\%. Setelah dikeringkan kadar air berkurang menjadi 6,4 $\pm 0,1 \%$. Hasil kadar air pliek $u$ dapat dilihat pada Gambar 4. 


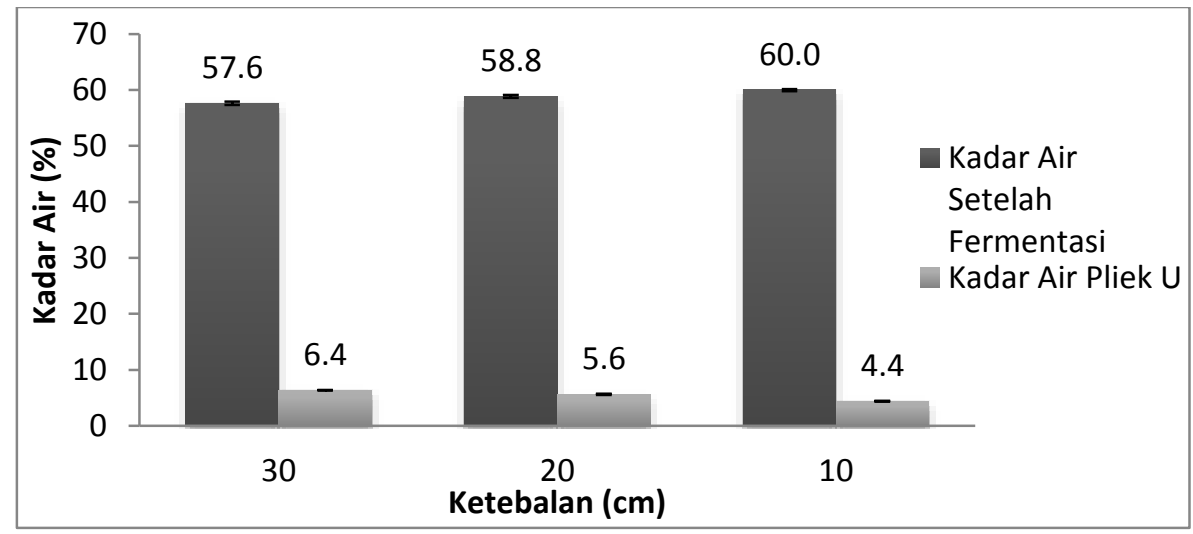

Gambar 4. Kadar air pliek- $u$ selama pengeringan

Kadar air sangat berpengaruh terhadap kualitas, dikarenakan semakin tinggi kadar air pada bahan maka bahan akan lebih mudah berjamur. Hal ini sejalan dengan hasil penelitian Khathir dkk (2015) menyatakan, kadar air yang tinggi dapat menyebabkan terjadinya infeksi jamur dan kapang serta menunjang terjadinya proses oksidasi dan hidrolisis pada minyak.

Kandungan kadar air pada suatu bahan sangat mempengaruhi terhadap daya tahan bahan tersebut, semakin tinggi kadar air pada suatu bahan maka semakin rendah daya simpan bahan. Menurut Suprati (2003), kandungan air merupakan salah satu faktor yang mempengaruhi daya tahan suatu produk, semakin rendah kadar air dari produk akan memperpanjang daya simpan suatu bahan, sebaliknya jika bahan yang dikeringkan tidak terlalu kering daya simpan akan semakin rendah. Ketentuan kadar air maksimal suatu produk berbeda beda sesuai dengan jenis produknya.

\section{Derajat Keasaman (pH) Pliek-U}

Nilai $\mathrm{pH}$ kelapa setelah fermentasi yang dihasilkan untuk ketebalan $30 \mathrm{~cm}$ yaitu 5,15 $\pm 0,4$, setelah dikeringkan nilai $\mathrm{pH}$ pliek $u$ yang dihasilkan yaitu $5,22 \pm 0,36$. Nilai $\mathrm{pH}$ kelapa setelah fermentasi yang dihasilkan untuk ketebalan 20 $\mathrm{cm}$ yaitu 4,86 $\pm 0,04$, setelah dikeringkan nilai $\mathrm{pH}$ pliek $u$ yang dihasilkan yaitu $4,93 \pm 0,02$. Ketebalan 10 nilai $\mathrm{pH}$ kelapa setelah fermentasi yang dihasilkan sebesar $4,31 \pm 0,1$, setelah dilakukan pengeringan hasil $\mathrm{pH}$ pliek $u$ yaitu 4,39 $\pm 0,1$. Nilai derajat keasaman $(\mathrm{pH})$ dapat dilihat pada Gambar 5.

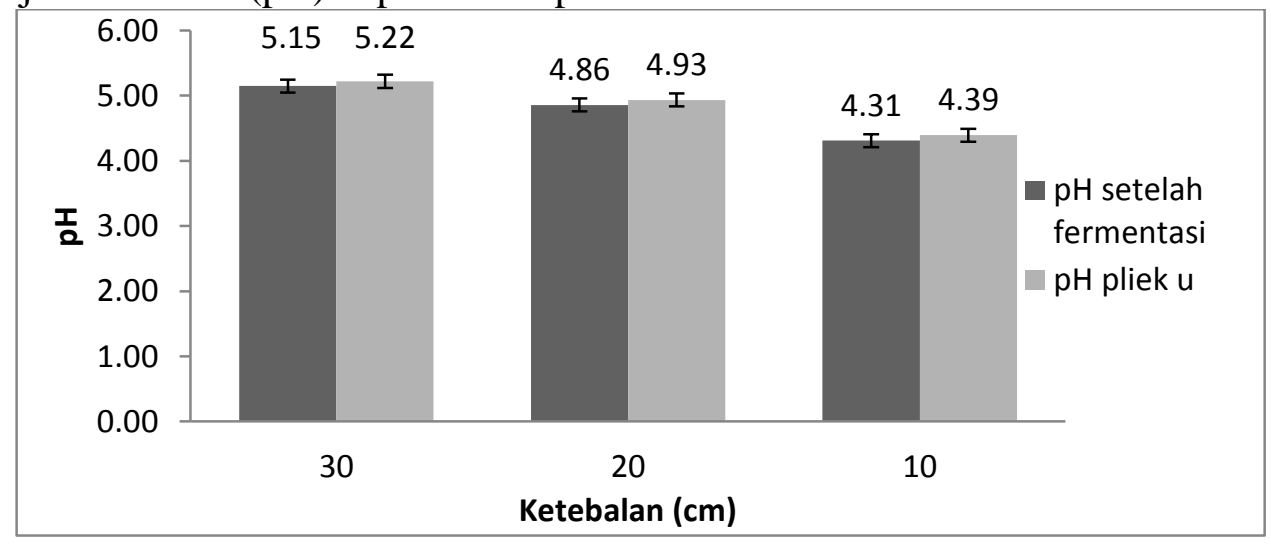

Gambar 5. Derajat keasaman $(\mathrm{pH})$ pliek- $u$ 
Berdasarkan dari Gambar 7. dapat dilihat bahwa hasil $\mathrm{pH}$ pliek $u$ lebih besar dibandingkan $\mathrm{pH}$ kelapa setelah fermentasi, namun nilai yang dihasilkan tidak melebihi angka 7 (netral). Pengukuran $\mathrm{pH}$ pada produk olahan makanan ini penting, karena menurut Rienoviar dan Nashrianto (2010) nilai pH yang stabil menunjukkan bahwa proses distribusi dari bahan dasar merata. Nilai $\mathrm{pH}$ ini juga berhubungan dengan kualitas produk yang berkaitan dengan pengolahan maupun pengawetan makanan.

\section{Asam Lemak Bebas (\%FFA)}

Pengukuran asam lemak bebas dilakukan pada minyak pliek yang dihasilkan dari pengepresan pliek $u$. Pengukuran asam lemak bebas minyak pliek dilakukan setelah selesai pengeringan. Hasil pengukuran kadar asam lemak bebas pada minyak pliek dapat dilihat pada Gambar 6.

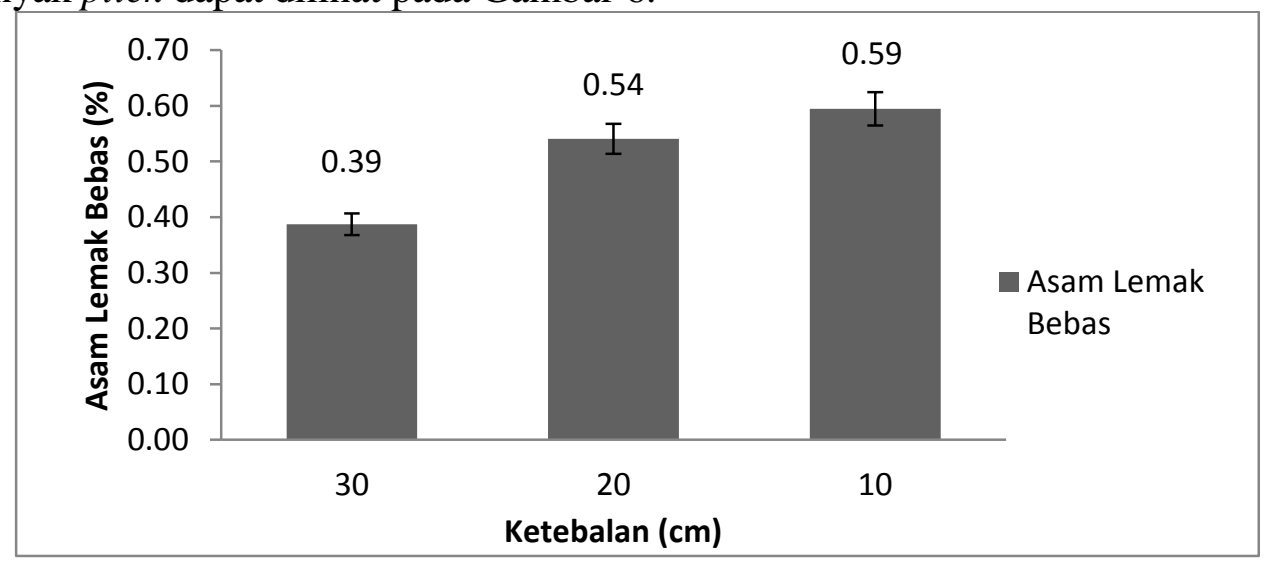

Gambar 6. Asam lemak bebas minyak pliek

Berdasarkan dari Gambar 6. dapat kita lihat adanya perbedaan asam lemak bebas (\%FFA) pada setiap ketebalan. Pada ketebalan $30 \mathrm{~cm}$ asam lemak bebas yang didapat sebanyak $0,39 \pm 0,1 \%$, ketebalan $20 \mathrm{~cm}$ asam lemak bebas yang dihasilkan sebesar $0,54 \pm 0,2 \%$, sedangkan pada ketebalan $10 \mathrm{~cm}$ asam lemak bebas yang dihasilkan sebesar $0,59 \pm 0,3 \%$.

Tabel 2. Standar Mutu Minyak Kelapa

\begin{tabular}{clc}
\hline No & \multicolumn{1}{c}{ Karakteristik } & Syarat mutu \\
\hline 1. & Kadar air $(\%)$ & Maks. 0.5 \\
2. & Kadar kotoran $(\%)$ & Maks. 0.05 \\
3. & Bilangan Jod (mg jod/100 g contoh) & $8-10$ \\
4. & Bilangan peroksida (mg oksigen/g contoh) & Maks. 5 \\
5. & Bilangan penyabunan (mg KOH/g contoh) & $255-265$ \\
6. & Asam lemak bebas & Maks. 5 \\
7. & Warna, bau, aroma & Normal \\
\hline
\end{tabular}

Sumber: $\quad$ SNI 01-2902-1992 dalam Asri dan Yanti, 2012.

Nilai asam lemak bebas yang paling tinggi terdapat pada ketebalan $10 \mathrm{~cm}$ dengan nilai $0,59 \%$, sedangkan asam lemak bebas yang paling rendah terdapat pada ketebalan $30 \mathrm{~cm}$ dengan nilai $0,39 \%$, dalam arti asam lemak bebas yang didapat dalam penelitian ini telah memenuhi syarat SNI dengan nilai ketentuan maksimum 
$5 \%$, hal tersebut dapat dilihat pada Tabel 2. Jadi, kualitas yang terbaik untuk minyak pliek terdapat pada ketebalan $30 \mathrm{~cm}$, karena menurut Muamawah, dkk (2014), kadar asam lemak bebas yang terlalu tinggi dapat mempercepat pertumbuhan mikroorganisme yang akan merusak komponen lemak sehingga menimbulkan bau tengik dan menyebabkan emulsi menjadi tidak stabil.

\section{Organoleptik}

\subsection{Pliek $U$}

1. Warna

Penilaian uji organoleptik pliek $u$ terhadap warna pada ketebalan $30 \mathrm{~cm}$ panelis memilih suka (2), ketebalan $20 \mathrm{~cm}$ panelis memilih netral (3), dan ketebalan $10 \mathrm{~cm}$ panelis memilih netral (3). Panelis menilai bahwa warna pliek $u$ yang bagus yaitu berwarna agak kecoklatan dan tidak begitu hitam seperti yang ditunjukkan pada sampel $30 \mathrm{~cm}$ yaitu suka (2). Sesuai dengan pendapat Winarno (2002), yakni secara visual faktor warna tampil lebih dahulu dan kadang-kadang sangat menentukan. Suatu bahan yang dinilai bergizi, enak, dan teksturnya sangat baik tidak akan dimakan apabila memiliki warna yang tidak sedap dipandang atau memberi kesan telah menyimpang dari warna yang seharusnya.

2. Aroma

Pliek $u$ memiliki aroma yang khas, penilaian uji organoleptik terhadap aroma pliek $u$ pada ketebalan $30 \mathrm{~cm}$ panelis memilih suka (2), ketebalan $20 \mathrm{~cm}$ panelis memilih netral (3), dan ketebalan $10 \mathrm{~cm}$ panelis memilih netral (3). Ini menunjukkan bahwa panelis masih dapat menerima aroma dari semua sampel pliek $u$, namun dari ketiga perlakuan panelis lebih menerima sampel dengan ketebalan $30 \mathrm{~cm}$.

\section{Rasa}

Pada umumnya pliek $u$ memiliki rasa yang asam, penilaian uji organoleptik oleh panelis pada ketebalan $30 \mathrm{~cm}$ panelis memilih suka (2), $20 \mathrm{~cm}$ panelis memilih suka (2), ketebalan $10 \mathrm{~cm}$ panelis memilih netral (3). Menurut panelis, pliek $u$ yang disukai adalah pliek $u$ yang memiliki rasa sedikit asam, berlemak dan kering, sedangkan yang tidak disukai adalah pliek $u$ yang terasa sedikit berminyak.

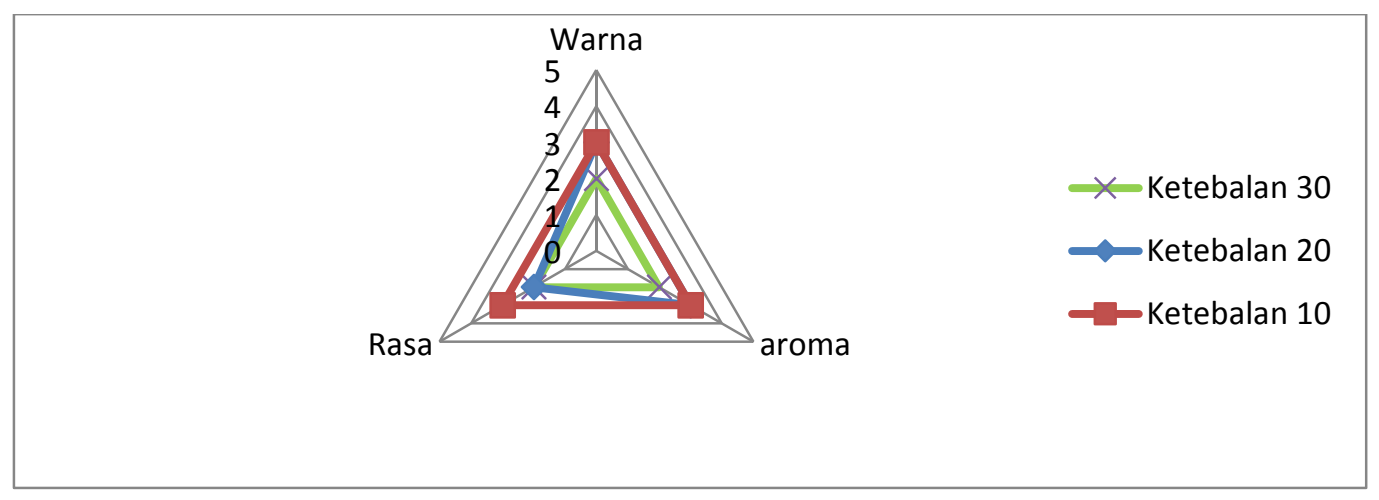

Gambar 7. Organoleptik pliek $u$

\subsection{Minyak Pliek}




\section{Warna}

Penilaian uji organoleptik minyak pliek terhadap warna pada sampel ketebalan $30 \mathrm{~cm}$ panelis memilih suka (2), ketebalan $20 \mathrm{~cm}$ panelis memilih suka (2), dan ketebalan 10 panelis memilih netral (3). Panelis menilai bahwa warna minyak pliek yang bagus yaitu berwarna bening seperti yang ditunjukkan pada sampel ketebalan $30 \mathrm{~cm}$ panelis memilih suka (2).

2. Aroma

Penilaian uji organoleptik minyak pliek terhadap aroma pada sampel ketebalan $30 \mathrm{~cm}$ panelis memilih suka (2), $20 \mathrm{~cm}$ panelis memilih suka (2), ketebalan $10 \mathrm{~cm}$ panelis memilih netral (3). Panelis menilai bahwa ketebalan $30 \mathrm{~cm}$ yang disukai.

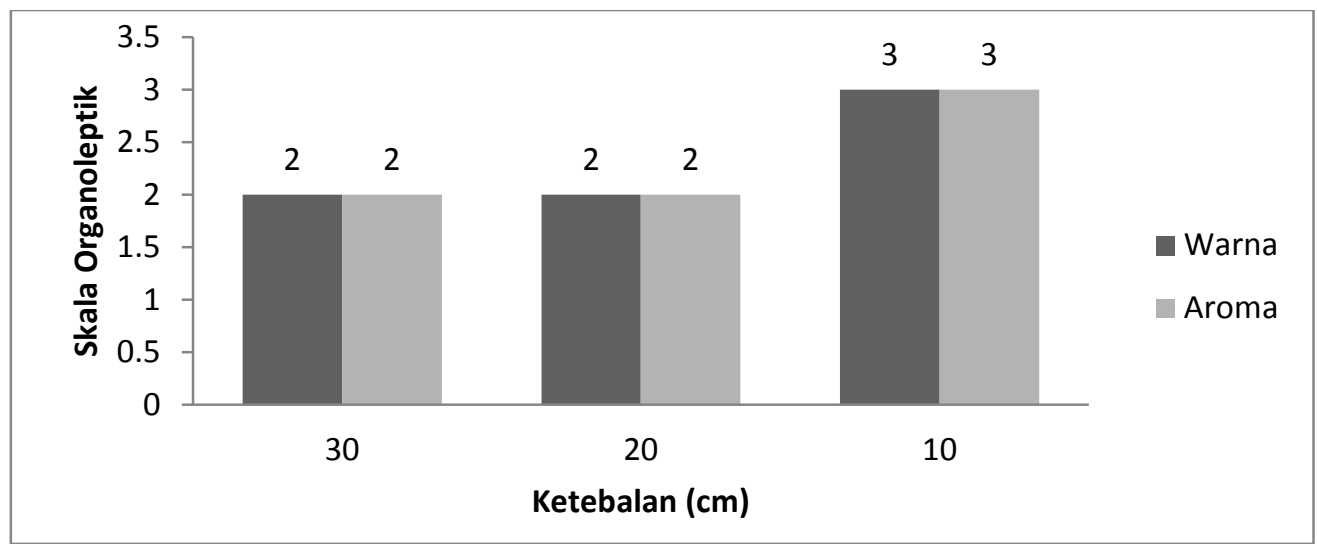

Gambar 8. Organoleptik minyak pliek

Hasil uji organoleptik keseluruhan menunjukkan bahwa pliek $u$ dan minyak pliek yang paling diterima oleh masyarakat yaitu ketebalan tumpukan pada saat fermentasi $30 \mathrm{~cm}$. Panelis memberikan penilaian yang baik dan paling disukai secara keseluruhan mulai dari warna, aroma, dan rasa.

\section{Kesimpulan}

\section{KESIMPULAN DAN SARAN}

1. Kadar air setelah fermentasi dan kadar air pliek $u$ yang dihasilkan pada setiap variasi ketebalan $30 \mathrm{~cm}, 20 \mathrm{~cm}$ dan $10 \mathrm{~cm}$ relatif sama, yakni berkisaran antara $57,6 \%-60,0 \%$ untuk kadar air setelah fermentasi dan 4,4\% - 6,5\% kadar air pliek $u$.

2. Hasil $\mathrm{pH}$ pliek $u$ masih kategori asam dengan nilai $\mathrm{pH}$ tertinggi 5,22 pada ketebalan $30 \mathrm{~cm}$, dan nilai terendah 4,39 pada ketebalan $10 \mathrm{~cm}$.

3. Secara keseluruhan minyak pliek yang dihasilkan masih memenuhi standar SNI. Minyak pliek yang dihasilkan dari ketebalan $30 \mathrm{~cm}$ yang memiliki kualitas terbaik karena memiliki kadar asam lemak bebas terkecil yaitu sebesar 0,39\%.

4. Hasil pengujian organoleptik terhadap pliek $u$ dan minyak pliek dapat disimpulkan bahwa masyarakat lebih menerima pliek $u$ dan minyak pliek dengan ketebalan fermetasi $30 \mathrm{~cm}$.

\section{Saran}


Adapun saran yang dapat ditambahkan untuk penelitian selanjutnya, yaitu adanya perlakuan ketebalan tumpukan fermentasi $30 \mathrm{~cm}$ yang dikeringkan dengan alat yang berbeda.

\section{DAFTAR PUSTAKA}

Asri, N., L. Yanti. 2015. Identifikasi dan analisa mutu minyak kelapa di tingkat petani provinsi jambi. Balai Pengkajian Teknologi Pertanian Jambi.

Khathir, R., Ratna, R. Agustina. 2015. Modifikasi alat pengering tipe hohenhiem untuk pliek-u. Laporan Penelitian. Program Studi Teknik Pertanian, Fakultas Pertanian, Universitas Syiah Kuala, Banda Aceh.

Muamawah, I.A.U., B. Setiaji, dan A. Syoufian. 2014. Pengaruh konsentrasi virgin coconut oil (VCO) terhadap stabilitas emulsi kosmetik dan nilai sun protettion factor (SPF). Jurnal Laboratorium Kimia Fisika, Jurusan Kimia, Fakultas Matematika dan Ilmu Pengetahuan Alam, Universitas Gadjah Mada, Yogyakarta. 24 (1) : 1-11.

Nurliana, M., Sudarwanto, L.I. Sudirman, dan Sanjaya A.W. 2009. Prospek makanan tradisional Aceh sebagai makanan kesehatan. Deteksi Awal Aktivitas Antimikrob. Jurnal Forum Pascasarjana. 32 (1) :1-10.

Rienoviar dan Nashrianto, H. 2010. Penggunaan asam askorbat (vitamin c) untuk meningkatkan daya simpan sirup rosella (Hibiscus sabdariffa Linn.). Jurnal Hasil Penelitian Industri. 23: 8-18.

Romano. 2013. Potensi produksi dan kinerja investasi industri pengolahan kelapa terpadu di Provinsi Aceh. Jurnal Agrisep. 14: 1-9.

Suhardiyono, L. 1988. Tanaman Kelapa Budidaya dan Pemanfaatannya. CV. Kanisius, Yogyakarta.

Suprapti, M.L. 2003. Teh Jamsi dan Manisan Nata Berkasiat Obat. CV. Kanisius. Yogyakarta.

Taib, G., Said, G., dan Wiraatmadja, S. 1988. Operasi Pengeringan Pada Pengolahan Hasil Pertanian. Mediyatma Sarana Perkasa. Jakarta.

Taufiq, M. 2004. Pengaruh Tempratur Terhadap Laju Pengeringan Jagung Pada Pengering Konvensional dan Fluidized Bed. Hasil Penelitian. Universitas Sebelas Maret, Surakarta.

Winarno, F. G. 2002. Kimia Pangan dan Nutrisi. PT. Gramedia Pustaka Utama, Jakarta. 